\title{
Some Representations of Aristocratic \\ Women in Islamic Art
}

\section{Heba Mahmoud Saad Abdel Naby}

\section{Abstract:}

The main goal of the study is to investigate whether aristocratic women were represented in Islamic art or not. The study, therefore, aims to present a variety of scenes of aristocratic women from the different parts of the eastern Islamic regions ranging from the $8^{\text {th }}$ to the $17^{\text {th }}$ century. The scenes in which aristocratic women were the main characters will be described then analyzed in order to reveal the activities of aristocratic women in such scenes, the frequency of the scenes and their date, their materials and their meaning. In addition, the study aims to disclose the fashions of clothes and headdresses of aristocratic women that could be witnessed from the scenes.

Key words: aristocratic women, painting, headdresses, styles of clothes

\section{Introduction}

Although the Islamic art is generally considered as nonfigural art, figural decorative themes were witnessed in Islamic art in certain periods and regions, moreover, occupied a prominent role in characterizing the art. Figural themes marked the early Islamic art under the impact of Greek, Coptic and Persian art. Thus, mural paintings and sculptures in secular architecture celebrated sporting activities, courtly scenes and female beauty with figural representations ${ }^{1}$. The figural themes were also among the main features of the Fatimid art. Portraits of court poets with excerpts of their poems were painted on the walls of the Fatimid pavilions. The arts of ceramics, metalwork, woodwork and glass were at their

\footnotetext{
- Associate Professor of Islamic Archeology Faculty of Tourism and Hotels

${ }^{1}$ Doris Behrens-Abouseif, Beauty in Arabic Culture, 1999, p. 135.
} 


\section{دراسات في آثار الوطن العربيء 1}

finest and most inventive at that era and were often decorated with figural scenes ${ }^{2}$. The scenes reflect an interest in naturalism which may have been due to a closer observation of everyday life. Such scenes included hunting, court scenes, dancers and musicians. The variety of figural themes even increased in the Iranian and Mesopotamian decorative arts of the $12^{\text {th }}$ and $13^{\text {th }}$ centuries. These themes were particularly shown on wall tiles, ceramics and metal ware. They included princely or royal scenes with a wide variety of scenes of royal games, dancers, musicians or drinkers in addition to the astronomic-astrologic scenes, mythological and literary themes and the scenes of love and meditation ${ }^{3}$. After the $14^{\text {th }}$ century, figural depiction disappeared in most of the Arab world while the Persian painting remained a rich source of such depictions.

The princely imagery played a prominent role among the figural motifs of Islamic art and previous studies discussed such scenes ${ }^{4}$. The studies proofed that the affluent life of caliphs and rulers was a rich source from which artists inspired their themes. In such scenes, the ruler was represented on the throne, surrounded by attendants and amused by musicians and dancers. The ruler was also represented in war and fight scenes, hunting birds or animals and enjoying leisure time by drinking or simply sitting in a garden or in outdoor scene.

Women were present in figurative scenes of the Islamic art but the examination of such scenes revealed that they were generally represented as musicians and dancers. That means they had a secondary role in the scene. But, one scene of a woman seated

\footnotetext{
${ }^{2}$ Jonathan Bloom and Sheila Blair, Islamic Arts, 1997, p. 249.

${ }^{3}$ Eva Baer, "A Brass Vessel from the Tomb of Sayyid Battal Ghazi. Notes on the Interpretation of Thirteenth-Century Islamic Imagery", Artibus Asiae, vol. 39, n. 3/4, 1977, p. 299.

${ }^{4}$ Barbra Brend, "A Kingly Posture: the Iconography of Sultan Husayn Bayqara" in The Iconography of Islamic Art; Studies in Honor of Robert of Hillenbrand, Bernard O'Kane (ed.), AUC, 2005, pp. 81-92; Abbas daneshvari, "Cup, Branch, Bird, and Fish: An Iconographical Study of the Figure Holding a Cup and a Branch Flanked by a Bird and a Fish", in The Iconography of Islamic Art; Studies in Honor of Robert of Hillenbrand, Bernard O'Kane (ed.), AUC, 2005, pp. 103- 125.
} 


\section{دراسات في آثار الوطن العربي؛ 1}

on a throne and surrounded by attendants, in a form similar to the traditional princely scenes, drew my attention ${ }^{5}$. Unlike the usual scenes, this one represents an aristocratic woman. That led me to inquire whether the aristocratic women were ever depicted in such figural themes or not. The present study, therefore, aims to present a variety of scenes of aristocratic women from the different parts of the eastern Islamic regions ranging from the $8^{\text {th }}$ to the $17^{\text {th }}$ century. The study aims also to analyze the scenes in which aristocratic women were the main characters to reveal the activities of aristocratic women in such scenes, the frequency of the scenes, their materials and their meaning. In addition, the study aims to disclose the fashions of clothes and headdresses of aristocratic women that could be witnessed from the scenes.

\section{The Descriptive Study}

A survey on scenes of various materials was made in search for scenes of aristocratic women. A criterion was set to differentiate aristocratic women from ordinary ones in order to choose the scenes that will be studied. In such scenes the woman was the focal point of the scene whether she was represented alone or accompanied with servants and attendants. Scenes of musicians and dancers were excluded.

The survey revealed that the scenes of aristocratic women could be divided into various types: the first type is the scene of enthroned woman. So far, only one scene has been discovered of this type. It is represented on a candlestick ${ }^{6}$ made for the Inju ruler of Fars, Abu Ishaq ${ }^{7}$. The base of the candlestick is encircled with

\footnotetext{
${ }_{6}^{5}$ Robert Hillenbrand, Islamic Art and Architecture, 1999,p. 205, fig. 160

${ }^{6}$ Brass candlestick inlaid with silver and gold and preserved in the Museum of Islamic Art at Doha-Qatar. It is attributed to the first half of the fourteenth century. http://www.lacma.org/khan/5/2.htm

${ }^{7}$ Injus dynasty controlled the southern Iranian province of Fars from about 703/1303 to 754/1353. It was called Inju after the term for royal estates distributed by the Mongols. Abu Ishaq was the last ruler of the Inju dynasty who ruled from 742/ 1341 to 754/1353. For more details see: E.J. Brill's First Encyclopedia of Islam, 1913-1936, p. 46; J.A. Boyle, "InDju”, The
} 


\section{دراسات في آثار الوطن العربيء 1}

four medallions; two of them are representing the enthroned ruler, one is representing the ruler together with his consort on a platformlike throne, and the fourth medallion is representing his consort alone on her throne (pl. 1, 1-b). The ruler's wife is represented seated on a square-shaped throne decorated with three lozenges and floral decorations. She is wearing a long dress with wide sleeves in addition to the headdress worn by married Mongol women known as bughtaq. She is surrounded by four attendants, two on each side. The one to the right is raising her hand with a square object that might be a mirror, and holds the hand of the attendant next to her. On the left, one attendant is seen carrying a toilet or jewelry box and the other is carrying a plate or tray with round things on it, probably fruits. The enthroned woman is surrounded with the same number of attendants as her husband in the other medallions while her throne is more decorated than that of her husband.

Another type of scenes with more frequent representations of aristocratic women is the scene of a woman in a hawdag. It is known that the hawdag was a compartment usually covered with a dome and placed on the back of a camel to be used for travel. It was covered with decorated cloth and generally used by women. The "hawdag" is one of many means of transportations that were used by the Arabs and it has many shapes and types ${ }^{8}$. It was mentioned by historians when they describe the procession of a Caliph's wife or a Sultan's wife or daughter travelling for pilgrimage 9 . Therefore, the hawdag was generally associated with wealthy and aristocratic women and thus the following scenes are scenes of aristocratic women.

\footnotetext{
Encyclopedia of Islam, vol. III, Leiden- London, 1986, p. 1208; Barbra Brend, Islamic Art, London, 1991, p. 124; Sheila R. Canby, Persian Painting, The British Museum, 1993, p. 36

${ }^{8}$ For more details about the hawdag, its types and similar means of transportations see: Abd alNasir Yasin, Wasa'el alsafar 'ind al Muslemin, Tarikhaha and atharaha- Derasa 'an alhawdag wa shakelatuh fi dawa almasader almaktuba wa alatharia, vol.1, Cairo, 2005.

${ }^{9}$ Kathryn Johnson, "Royal Pilgrims: Mamluk Accounts of the Pilgrimes to Mecca of the Khawand al-Kubra (Senior Wife of the Sultan)", Studia Islamica, n. 91, 2000, pp. 107-131; also see: J. Jomier, "Mahmal", The Encyclopedia of Islam, vol. VI, Leiden, 1991, pp.44-46.
} 


\section{دراسات في آثار الوطن العربيء 1}

The earliest scene of this group is the scene of a woman in a hawdag, represented on a luster painted plate attributed to the ceramist Muslim ${ }^{10}$. It shows a square hawdag with side curtains, surmounted with a triangular decorated top with a crescent on its top. Only the face of the woman inside the hawdag is seen and she is marked with a round face and a dreamy look (pl. 2). This scene is attributed to the $5^{\text {th }}$ century A.H./ $11^{\text {th }}$ century A.D. Three other similar scenes in Cappella Palatina ${ }^{11}$ were attributed to the $6^{\text {th }}$ A.H./ $12^{\text {th }}$ A.D. century. The first scene (pl. 3) shows a woman seated in a square hawdag also with side curtains, triangular top and a crescent on its top ${ }^{12}$. The second scene on Cappella Palatina (pl.4) shows a veiled woman inside a square hawdag with decorated side-curtains and triangular top ends with a floral motif on its topmost ${ }^{13}$. The third scene (pl. 5) shows a veiled woman inside a square hawdag with a triangular top but the hawdag is plain of decorations ${ }^{14}$. Only the bust of the woman in the hawdag is seen in the latter three scenes.

The Blacas ewer which was made in Mosul in 629 A.H./ 1232 A.D. ${ }^{15}$ bears another example of the scene of an aristocratic

\footnotetext{
${ }^{10}$ This plate is preserved in the Faculty of Arts Museum- Alexandria University and it bears the name of the ceramist Muslim whose work is attributed to the $5^{\text {th }}$ century A.H./ 11 A.D. Heba M. Saad and Delphine Dixneuf, Catalogue of the Faculty of Arts Museum- Alexandria University, Islamic Pottery, Centre d'Étude Alexandrines, 2012, Cat. n. 4, p. 10.

${ }^{11}$ Cappella Palatina is the private chapel of King Roger II which was completed around 1140A.D. in Palermo, Sicily. It is a hybrid structure consisting of a Byzantine-type sanctuary, combined with a Western nave having scenes from the Old Testament and a wooden ceiling in the Muslim manner. The ceiling is covered with a multitude of panels, with muqarnas units, representing various courtly activities, genre episodes, and religious scenes. The paintings are attributed to Arab artists brought from Egypt by Roger II and were following the Fatimid Style. Richard Ettinghausen, Arab Painting: Treasures of Islam, London, 1977, pp. 44-47; Wijdan Ali, The Arab Contribution to Islamic Art From the Seventh to the Fifteenth Centuries, 1998, p. 161; Richard Yeomans, The Art and Architecture of Islamic Cairo, 2006, p. 80.

${ }^{12}$ Richard Ettinghausen, "Painting in the Fatimid Period: A Reconstruction", Ars Islamica, vol. 9, 1942, p. 116, fig. 12

${ }^{13}$ Abd al-Nasir Yasin, Wasa'el alsafar, vol.2, p. 614-615, fig. 32

${ }^{14} \mathrm{R}$. Yeomans, The Art and Architecture, p. 81.

${ }^{15}$ Blacas ewer is made of brass and inlaid with gold and silver. It is preserved in the British Museum. The ewer was made by Shuja' ibn Mana al-Musili and it dates to 629 A.H./1232A.D.
} 


\section{دراسات في آثار الوطن العربيء}

woman in a hawdag. One of the medallions on the lower part of the ewer's body shows a wealthy lady in a camel-litter (pl. 6) ${ }^{16}$. It seems that the camel-litter was used by aristocrats as means of transportation in narrow streets inside cities not for travel as the traditional hawdag. The lady represented in the scene is accompanied by a bearded man who might be her servant and another servant is leading the camel. The lady is wearing a dress with long wide sleeves decorated with a tiraz band on the collar and around the sleeves, in addition to a turban on her head.

The story of Yusuf and Zulaykha provides another evidence of the use of hawdag for the travel of aristocratic women. According to the story, Zulaykha's father arranged her marriage to the governor (aziz) of Egypt and sent her to Egypt ridding her hawdag. The various copies of the story depicted that scene with variations of details. The manuscript of Yusuf and Zulaykha from the collection of Ussr shows Zulaykha in her hawdag which was hexagonal in shape and richly decorated with floral decorations. The opening of the hawdag shows the bust of Zulaykha who was wearing a colorful dress and a small scarf on her head ${ }^{17}$. The manuscript of Haft Awrang by Jami preserved at the Freer Art Gallery also depicts the scene of Zulaykha in her hawdag entering the capital of Egypt (pl.7) and being received by the Egyptians in festive atmosphere ${ }^{18}$. Zulaykha is represented in her hexagonal hawdag, which is richly decorated and surmounted with a dome, wearing a red dress and a small scarf. The same scene of Zulaykha traveling to Egypt in her hawdag was represented in several copies of the manuscript of Yusuf and Zulaykha such as one dates to

For more details about Blacas ewer see:

http://www.britishmuseum.org/explore/highlights/highlight_objects/me/t/the blacas_ewer.aspx

${ }^{16}$ Rachel Ward, Islamic Metalwork, 1993, p. 82, fig. 60; Eva Wilson, Islamic Design, The British Museum Press, 1994, pp.16-17.

${ }^{17}$ Abd al-Nasir Yasin, Wasa'el alsafar, vol.2, pp. 578-579, fig. 10

${ }^{18}$ This painting is attributed to the Safavid period 1556-1565 A.D. The joyous, festive mood may well refer to the arrival of Sultan Ibrahim Mirza's royal cousin and future wife, GawharSultan Khanim, the eldest daughter of Shah Thamasb, in Mashhad in 1556, http://www.asia.si.edu/collections/singleObject.cfm?ObjectNumber=F1946.12.100 


\section{دراسات في آثار الوطن العربيء 1}

$1595^{19}$, and another dates to $1619^{20}$. The former scene represents Zulaykha in a square-shaped hawdag covered with a dome and carried by two horses instead of a camel as mentioned in the story. This form of hawdag was referred to by historians as mahaffah which is equivalent to the Persian name takhtarawan ${ }^{21}$. In the two scenes the hawdag is richly decorated and Zulaykha is seen inside wearing a colorful dress and a small scarf ${ }^{22}$.

The story of Layla and Majnun also presented scenes of Layla in a hawdag. The Khamsa by Nizami preserved in the National Library of Paris ${ }^{23}$ contains a scene of Layla visiting Majnun in the desert and she is represented inside a hawdag on a camel led by a servant ${ }^{24}$. The hawdag is simple with a square shape and a conical top decorated with interlacing lines. The arched opening of the hawdag reveals the bust of Layla who is looking towards Majnun.

Similar scenes inspired by the story of Layla and Majnun were also represented on textile. The first example is seen on a silk textile (pl. 8) dates to the 16 th or 17 th century ${ }^{25}$. It shows Layla inside a circular hawdag covered with a dome that is surmounted with a bird. Layla is wearing a dress with long sleeves covering her hands and her hair is probably uncovered. The camel is in movement position led by a servant and the lower part of the hawdag bears the phrase "made by Ghayath". Another example shows Layla inside a small square hawdag covered with a dome

\footnotetext{
${ }^{19}$ Abd al-Nasir Yasin, Wasa'el alsafar, vol.2, pp. 585-586, fig. 15

${ }^{20}$ This manuscript is preserved in the Museum of Islamic Art in Cairo. Zaki Mohamed Hassan, Al-Taswir fi al-Islam 'and al-Furs, 1936, pl. 44, fig. 56

${ }^{21}$ Abd al-Nasir Yasin, Wasa'el alsafar, vol.1, pp. 333-335.

${ }^{22}$ It is worth mentioning that many other scenes representing Zulaykha in her hawdag were mentioned by Abd al-nasir Yasin in his study and were representing Zulaykha in her hawdag, going to the market or to her palace, and the camel was generally led by a servant. Abd alNasir Yasin, Wasa'el alsafar, vol.2, fig. 11, 13, 14, 21, 22, 27

${ }^{23}$ This manuscript of Khamsa by Nizami dates to the end of the $9^{\text {th }}$ century A.H./ $15^{\text {th }}$ century A.D.

${ }^{24}$ Abd al-Nasir Yasin, Wasa'el alsafar, vol.2, fig. 28

${ }^{25}$ Barbra Brend, Islamic Art, pl. 115; Patricia Baker, Islamic Textiles, British Museum Press, 1995, p.107
} 
دراسات في آثار الوطن العربيء 1

surmounted with a trilobed leaf on its top ${ }^{26}$. The lower part of the hawdag is decorated with pointed star pattern. Layla is seen inside the hawdag, wearing a dress and a scarf, and holding the bridle of the camel.

Another interesting scene of a woman in a hawdag is seen on a luster-painted bowl dates to 611 A.H./ 1214 A.D. ${ }^{27}$. It shows a woman inside a hawdag carried by an elephant not a camel. The woman is veiled and covering her face, revealing only the eyes. The hawdag is in the form of an open litter with two side supports ending with almond shape. The back of the elephant is covered with a large piece of cloth, with rich floral decorations, fastened on the back of the elephant with straps. The elephant has a bell hanging in the neck to warn pedestrians from the elephant and also indicates that an important personality is passing ${ }^{28}$.

The third type of scenes of aristocratic women depicts $\underline{\text { a }}$ woman looking in a mirror. The first example of this scene is represented on the Cleveland ewer $^{29}$ which was made in Mosul in 620 A.H./ 1223 A.D. The body of the ewer is decorated with five large polylobed medallions, one of which is our concern (pl. 9) ${ }^{30}$. The scene in the medallion depicts an enthroned figure, crosslegged and holding a mirror in the raised left hand. In front of the woman, there are two attendants; one is carrying a toilet box and the other is holding a fly whisk. A lion is shown at the bottom of the scene and two affronted peacocks on its top. Most of the silver inlay of the ewer has vanished and that makes the identification of the sex

\footnotetext{
${ }^{26}$ Abd al-Nasir Yasin, Wasa'el alsafar, vol.2, fig. 61

${ }^{27}$ This bowl is preserved in the collection of J.O. Motossian in Buenos Aires, Argentina. Abd al-Nasir Yasin, Wasa'el alsafar, vol.2, fig. 47

${ }^{28}$ Abd al-Nasir Yasin, Wasa'el alsafar, vol.2, p. 640

${ }^{29}$ The Cleveland ewer is preserved in the Cleveland Museum of Art. It is made of brass and inlaid with silver. It was made by Ahmad al-Dhaki al-Mawsili. David Rice, "Inlaid Brasses from the Workshops of Ahmad al-Dhaki al-Mawsili", Ars Orientalis, 1957, p.287

${ }^{30}$ D. Rice, "Inlaid Brasses", p. 295, fig. 13 and for the photo of the whole ewer see: http://www.britannica.com/EBchecked/media/72069/Mosul-brass-ewer-1223-in-theCleveland-Museum-of-Art
} 


\section{دراسات في آثار الوطن العربي؛ 1}

of the figures rather difficult. But we might suggest that the enthroned figure is a woman judging on the long lines representing the hair, the mirror in the left hand and the attendant offering her a toilet or jewelry box. The presence of the throne with the loin underneath- which is kingly attribute- might also suggest that the represented woman is not only an aristocratic woman but the wife of a ruler or governor. Similar composition supporting that suggestion was seen on Abu Ishaq candlestick (pl.1) although it is of latter date.

The second example of this type of scenes is represented on Blacas ewer. It is seen on a medallion on the lower part of the ewer's body $(\mathrm{Pl} .10)^{31}$. It depicts two women: the aristocratic woman is seated cross-legged and looking in a mirror which she holds in her raised left hand, while her attendant is standing in front of her carrying a hexagonal box. The aristocratic woman is wearing a dress with v-shaped collar and wide sleeves. It is decorated with a tiraz band on the collar, the upper part of the arm, the end of the sleeves and the lower end of the dress. She is also wearing a small turban with a diamond shape on its front and a long band hanging on her back. The attendant seems to be short and ugly. She is carrying a box that might be containing cosmetics or jewelry.

The fourth type of scenes of aristocratic women represents $\underline{a}$ woman reclining on a couch, either alone or surrounded by attendants and usually in an outdoor scene. The oldest known scene in this category is depicted on the Cleveland ewer, on one of the five large polylobed medallions on its body (pl. 11). It shows a figure reclining on a couch with the right arm bent behind the head and the left arm bent in front of the body. Seated at the feet of the reclining figure is another person (male or female) holding a beaker or a bouquet in the outstretched right hand. A standing figure in the rear is carrying a long-necked bottle. The remaining spaces of the

\footnotetext{
${ }^{31} \mathrm{http}: / / \mathrm{www} . \mathrm{scalarchives} . \mathrm{com} / \mathrm{web} /$ ricerca risultati.asp?nRisPag=24\&prmset=on\&ANDOR=a

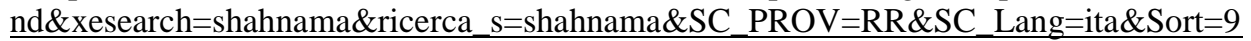




\section{دراسات في آثار الوطن العربي؛ 1}

scene are filled with trees and birds ${ }^{32}$. Again the disappearance of the silver inlay hinders the identification of the sex of the depicted figures but we might suggest that at least the main figure represents a woman. That suggestion is based on the graceful feminine posture of the figure reclining on the couch. It is hard to believe that a male would be represented in such a posture. Moreover, the same posture was repeated later in Persian paintings with very similar details as will be described in the following scenes.

Several scenes of women reclining on a couch were witnessed in Islamic Painting. One scene is depicted in a copy of the Shahnama attributed to the $15^{\text {th }}$ century and preserved in the Freer Gallery of Art (pl.12) ${ }^{33}$. It shows a woman reclining on a couch in an outdoor scene. The couch looks more like a bed and the woman is reclining on it, bending her body and covering the lower part of her legs. The woman is veiled and is wearing a long dress. She is surrounded by servants and attendants. One attendant is sitting on the left side of the couch holding the lady's arm, another is sitting on the right side offering her a small book, a third is sitting raising her arms carrying a hexagonal box, a fourth is offering the lady two small bottles, probably of perfume. A fifth attendant is standing at the feet of the lady carrying a box that might be a toilet or jewelry box and the sixth attendant is standing on the opposite side. The background is covered with floral decorations and a large tree is shedding the lady.

Another scene of an aristocratic woman reclining represents Bilqis, the queen of Sheba in an outdoor scene (pl. 13). The painting is attributed to the second half of the $16^{\text {th }}$ century and it is preserved in the British Museum in London ${ }^{34}$. It represents Bilqis

\footnotetext{
${ }^{32}$ D. Rice, "Inlaid Brasses", pp. 295- 298, fig. 15

${ }^{33}$ This is a folio of Shahnama by Firdawsi (d. 1020) that is attributed to the third quarter of the $15^{\text {th }}$ century A.D. It is preserved in the Freer Gallery of Art. http://www.asia.si.edu/collections/singleObject.cfm?ObjectNumber=S1986.139

${ }^{34}$ This painting is from album painting in Qazvin style, about 1590. Its attribution to Bihzad in the right upper corner is posterior. Ernst Kühnel, Miniaturmalerei im Islamischen Orient, Berlin, 1923, p. 99; Barbra Brend, Islamic Art, p. 166, pl.111.
} 


\section{دراسات في آثار الوطن العربيء 1}

reclining on two cushions on the ground in a feminine posture, looking at the hoopoe which is carrying a love letter from King Solomon. The queen is wearing a triangular-shaped headdress and a long dress covering all her body except the feet. A long scarf is seen between her arms and two small cups in front of her. The background is occupied with a tree, under which Bilqis is reclining, and some plants and flowers.

A third scene of the same category is also attributed to the $16^{\text {th }}$ century $^{35}$ (pl.14). It is attributed to Bukhara school and represents a woman reclining in a feminine posture with the upper part of her body naked while the lower part is wrapped with a piece of cloth. The woman's left arm is bent behind the head and the right arm is bent in front of the body concealing her breast and her feet are crossed. The woman's hair is not covered and descends over her back.

The fifth type of scenes represents portraits of aristocratic women either standing or sitting and generally in an outdoor scene. We have several examples of those portraits such as the one attributed to the second half of the $16^{\text {th }}$ century and represents a seated princess ${ }^{36}$ with a flower in her hand (pl. 15). The princess is marked with her round face with fine features and connected eyebrows which was a characteristic feature of Persian aristocratic women. She is wearing a cloak embroidered on the shoulders and front and reveals the dress underneath that has long sleeves covering the princess's left hand while she holds a flower in her right hand. She is also wearing a headdress with a crown on it. She is wearing long earrings, bracelet, necklace and a ring.

\footnotetext{
${ }^{35}$ Ernst J. Grübe, The Classical Style in Islamic Painting: The Early School of Heart and its Impact on Islamic Painting in the later $15^{\text {th }}, 16^{\text {th }}$ and $17^{\text {th }}$ centuries, 1968, pl. 50

${ }^{36}$ This painting is preserved in the Courtesy of Fogg Art Museum, Harvard University. It is attributed to Qazwin style and dated 1550 A.D. B. W. Robinson, Persian Drawings from the $14^{\text {th }}$ Century Through the $19^{\text {th }}$ Century, London, 1965 , Pl.44.
} 


\section{دراسات في آثار الوطن العربيء 1}

Another portrait attributed to the same era represents a young aristocratic woman standing with a fan in her hand (pl. 16) ${ }^{37}$. She is wearing a green cloak closed from front with buttons, over a purple dress with long sleeves. She is wearing a small scarf tied below her chin, revealing part of her hair, and decorated with a golden motif above the forehead. Similar to the previous example, the woman is wearing jewelry including bracelets and necklace.

A third example is a portrait attributed to the $17^{\text {th }}$ century $^{38}$ depicting a seated aristocratic woman arranging her hair (p1.17). She has a round face with fine features and connected eyebrows which emphasizes her aristocratic standard. She is wearing a long cloak closed with buttons at front and a belt, together with a dress and colorful trousers underneath it. She is also wearing a triangular-shaped headdress with a feather on the forehead. The portrait of a woman counting her fingers is also attributed to the same group of paintings and dates to the same era $^{39}$. The depicted woman is seated (pl. 18), wearing a mustardyellow dress decorated with birds and animals together with a long purple cloak descending on her back. She is also wearing a triangular shaped headdress over a green veil that covers half her body but reveals side hair locks. There is a small bottle in front of the woman while trees and plants are surrounding her.

\section{The Analytical Study}

Women have always been present in the figural themes of Islamic art. They were generally represented as musicians, dancers $^{40}$ and attendants in court scenes, thus were engaged in

\footnotetext{
${ }^{37}$ This painting is attributed to Aqa Riza and dated 1590 A.D. It is preserved in the Courtesy of the Smithsonian Institution, Freer Gallery of Art. B.W. Robinson, Persian Drawings, P1.54

${ }^{38}$ This painting is preserved in Victoria and Albert Museum, London and dated 1610-20. B.W. Robinson, Persian Drawings, Pl.64

${ }^{39}$ This painting is preserved in Bibliothèque Nationale, Paris. It is attributed to the painter Riza Abbasi and dated ca. 1630 A.D. B.W. Robinson, Persian Drawings, Pl.61

${ }^{40}$ Previous studies paid attention to female figures in Islamic art in general while other studies focused on the study of musicians in Islamic art-including women. For example see: Walter Denny, "Music and Musicians in Islamic Art", Asian Music, vol.17, n.1, 1985; Salah Bahnasi,
} 


\section{دراسات في آثار الوطن العربي؛ 1}

various activities usually related to the entertainment of the main character in the scene. Such scenes were common in early Islamic art and generally reflected foreign influences ${ }^{41}$. The women in such scenes seem to be depicted in passive roles, relegated to mere "wall-flowers" rather than participants of a live scene ${ }^{42}$.

The present study presents a different category of scenes in which women played the main role. All the scenes represent aristocratic women who were the main character of the scenes. The women in the scenes were identified as aristocrats by their clothes, jewelry, headdresses, and servants surrounding them or the context of the scene. The analysis of the scenes could reveal various facts and explanations about the scenes:

\section{Variety of scenes}

The above-mentioned scenes proved that the Muslim artist represented aristocratic women in a variety of scenes some of which are related to their public activities while others are more private. The scene of enthroned women is classified among the first type; the public-related activities. Although it is so far the only scene known of this type but it indicates that the some wives of kings and rulers gained importance and might have practiced some responsibilities that gave them power and leadership. In fact the tradition of women exercising real power ran as clear thread through the Turko-Mongol dynasties and was witnessed by historians in several Islamic dynasties ${ }^{43}$. The substantial power of

Manazir al-Tarab wa al-Musiqa fi al-Taswir al-Irani, 1990; Eva Baer, "The Human Figure in Early Islamic Art: Some Preliminary Remarks", Muqarnas, vol. 16, 1999; Myriam RosenAylon, "The female Figure in Umayyad Art" in In Pursuit of Gender: Worldwide Archaeological Approaches, 2002; Rina Talgam, The Stylistic Origins of Umayyad Sculpture and Architectural Decoration, 2004; Ahmad Mousa Abd al-Tawab, Manazir al-Musiqa wa alTarab 'Ala al-Qitaa al-Faniya fi Misr al-Fatimia, Master Thesis, Faculty of Tourism and Hotels, Alexandria University, 2008.

${ }^{41}$ Richard Ettinghausen, "Painting in the Fatimid Period", p. 115; Oleg Graber, "Islamic Art and Byzantium", Dumbarton Oaks Papers, vol.18, 1964, p.84; K.A.C. Creswell, Early Muslim Architecture, vol.1 -II, 1969.

${ }^{42}$ Maryam Rosen-Ayalon, "The Female Figure", p. 294.

${ }^{43}$ For more details about women exercising power in different times and regions see: Gawin R.G. Hambly (edit.), Women in the Medieval Islamic World, 1989, pp. 10-22. 


\section{دراسات في آثار الوطن العربيء 1}

such women could have inspired artists to represent them enthroned in a posture similar to the ruler himself.

The scene of an aristocratic woman in a hawdag or mahaffah could also be classified among the public-related scenes. It shows her when she goes out either for pilgrimage, traveling from place to another or simply going to the market or for a walk in the city. Such scenes give us a good idea about means of transportation used by wealthy ladies and their variations according to their usage. The hawdag was a covered compartment suitable for long travels while the camel-litter was used for short distances within the city. Furthermore, the hawdag, camel-litter, mahaffah or takhtarawan were all used to show off the wealth of their owner. Therefore, they were made of rich decorated fabrics and varied in shape and decorations. Moreover, such scenes give us an idea about how aristocratic women dress up when they go out since they were seen by the public. Therefore, the artist paid attention to the details such public-related scenes reflecting luxury in clothes and decorations.

The second type of scenes is inspired by the private lives of aristocratic women thus representing the woman looking in a mirror as if putting make up or reclining on a couch or a cushion usually in an outdoor scene. In most of these scenes the aristocratic woman was accompanied with servants or attendants either female or male. Unlike the first classification of scenes, such scenes of the private daily activities of aristocratic women reflected intimacy and simplicity rather than luxury. The aristocratic women were represented with simple clothes, or even naked ${ }^{44}$, and usually barefooted.

The variety is also witnessed in the materials on which the scenes were represented. The study revealed that scenes of aristocratic women were represented on ceramics, metals, wood, textiles and above all painted manuscripts.

${ }^{44}$ Pl. 14 


\section{دراسات في آثار الوطن العربيء}

\section{Date of the scenes}

This group of scenes of aristocratic women makes us wonder: when was the first appearance of such scenes? Was the appearance of such scenes restricted to certain eras? and if so, why?

Arranging the scenes according to their date reveal that the oldest known scene of aristocratic woman is attributed to the eleventh century which is the scene of a woman in hawdag on a ceramic plate made by Muslim ${ }^{45}$. The three scenes on the ceiling of Cappella Palatina were also attributed to the same era which is the Fatimid era. Another group of scenes was attributed to the era between the twelfth to the fourteenth century. The third group of scenes was attributed to the sixteenth and seventeenth century. It is also noticeable that the early scenes of aristocratic women were witnessed in various materials while from the fourteenth century on such scenes were witnessed in painting only.

These facts would assure that the representation of aristocratic women was restricted to certain eras and in later times even restricted to certain materials. The reasons behind that are sought in the characteristic features of those eras. The Fatimid era is marked by the courtly scenes that were varied and included scenes of seated rulers with or without attendants, dancers, processions, and animals and with a wide range of themes ${ }^{46}$. Therefore, women were part of the luxurious court life but not a focal point of that life. For the artist, he used to see female attendants, dancers and musicians -those who were frequently depicted in Fatimid art- but the aristocratic women were only seen when they go out of the court for travel or pilgrimage .That is why "the aristocratic woman in a hawdag" was the only scene inspired from the lives of the elite ladies during the Fatimid period.

Then the second half of the twelfth century saw an unprecedented expansion of figural decorations, representing

\footnotetext{
${ }^{45} \mathrm{Pl} .2$

${ }^{46}$ Robert Hillenbrand, Islamic Art and Architecture, p. 68, Richard Yeomans, The Art and Architecture, p. 77
} 


\section{دراسات في آثار الوطن العربيء}

narrative scenes that include pictures of courtiers, animals, zodiacal themes and images from the princely cycle featuring hunting, banqueting, music-making and the like. Moreover, the patronage of the products, especially metalwork of the $12^{\text {th }}$ and $13^{\text {th }}$ century was exercised by persons of high rank and also a lower level of the society such as merchants, members of the learned class and professional people. Those were always imitating the high class in their lives or at least in their taste for art. No wonder that the artist inspired themes from the life of aristocratic people, presenting new scenes and introducing aristocratic women in varied contexts. This art, then, reveals a cross-section of contemporary society and its taste of luxury ${ }^{47}$.

The largest number of scenes of aristocratic women is witnessed in the paintings of the fourteenth, sixteenth and seventeenth century. In fact the art of painting itself is a luxury art. The chief patron of painters was the ruler, whether the caliph or in later times the sultan, the actual wielder of political power ${ }^{48}$. No wonder that painters inspired their topics from the luxurious life of the ruler, reflecting a life of comfort and beauty. Many painters lived under the patronage of rulers and sultans and lived in their palaces. Therefore, they had access to the private life of the aristocratic class and as a result inspired new scenes of the private lives of the aristocratic women.

\section{Fashions of clothes and headdresses}

The studied group of scenes can provide insight about the various fashions of clothes and headdresses of aristocratic women according to regions and eras.

The scenes show that aristocratic women were usually covering their hair with a veil, turban, or a scarf when they go out or when they are exposed to the public ${ }^{49}$. Only two scenes are

\footnotetext{
${ }^{47}$ R. Hillenbrand, Islamic Art and Architecture, p. 90

${ }^{48}$ R. Ettinghausen, Arab Painting, p. 14.

${ }^{49}$ Muslim women went out veiled in public since early times of Islam. Yedida Kalfon Stillman, Arab Dress from the Dawn of Islam to Modern Times- A short History, 2003. p. 56.
} 


\section{دراسات في آثار الوطن العربيء 1}

exceptions of that rule ${ }^{50}$. The headdress itself varies according to regions and eras. The Fatimid women were represented with a simple veil that covers all the hair and reveals only the face ${ }^{51}$. Sometimes a turban could be worn -together with the veil- that is made of a long piece of cloth furled around the forehead with many folds ${ }^{52}$. This turban might be the mi'jar which was worn by the elite women since the Umayyad times and was the female equivalent of the imama both in form and use ${ }^{53}$. Different types of headdresses were used by women in the eastern countries. The Inju queen was wearing a version of baqtaq or bughtaq, which is a headdress worn by married Mongol women ${ }^{54}$.On the other hand, the Persian women were usually wearing a small scarf that is tied behind the head or under the chin, revealing some hair locks on the forehead and the neck $^{55}$. Accessories and jewelry were sometimes added above the scarf to decorate the forehead ${ }^{56}$. Another headdress that was fashionable during the $16^{\text {th }}$ and $17^{\text {th }}$ century was triangular in shape and tied on the back of the head and sometimes decorated with a feather above the side of the forehead ${ }^{57}$.

On the other hand, the scenes that depict activities of the private lives of the aristocratic women usually represent them revealing their hair totally or partly ${ }^{58}$.

Similarly, the scenes depict various types of clothes. It seems that dresses with long wide sleeves were fashionable during the $12^{\text {th }}$ century till the $14^{\text {th }}$ century in Egypt, Syria and Persia ${ }^{59}$. They were made of plain or patterned cloth, had round or v-shaped collar and were decorated with bands of decoration- or tiraz- around the

\footnotetext{
${ }^{50} \mathrm{Pl} .2$ and 3

${ }^{51}$ Pl. 4 and 5

${ }^{52}$ Pl. 6-b

${ }^{53}$ Yedida K. Stillman, Arab Dress, p. 45.

${ }^{54}$ R. Hillenbrand, Islamic Art and Architecture, p. 205. See pl. 1-b

${ }^{55}$ See pl. 7, 8 and 16

${ }^{56}$ See pl. 16

${ }^{57}$ See pl. 13, 17 and 18

${ }^{58} \mathrm{Pl} .10,13,14$ and 15

${ }^{59}$ Pl. 6-b, 10 and 1-b
} 


\section{دراسات في آثار الوطن العربيء 1}

collar, on the arms and on the end of the sleeves. It seems that the fashion has changed in Persia by the second half of the $14^{\text {th }}$ century as dresses or robes had narrow sleeves and looked like a mantle that is opened in the middle and tied together by a belt ${ }^{60}$. We notice variations of this fashion during the $16^{\text {th }}$ and $17^{\text {th }}$ century; since the mantle or qaba' was sometimes made of patterned fabric ${ }^{61}$ or embroidered on the shoulders and chest ${ }^{62}$. The mantle had sometimes short sleeves revealing the robe underneath ${ }^{63}$ or was itself short revealing the trousers or sirwal underneath ${ }^{64}$.

\section{The spirit of realism}

The analysis of the aristocratic women scenes reflects a spirit of realism that was expressed by the Muslim artist. It seems that realism in Islamic art has been developed through several stages of development. In the first stage, during the Fatimid period, the art was a typical court art; thus inspired themes from the court life which were varied and new for that time. The artists paid attention to details of clothes, decorations, facial features and postures of the body thus reflecting a new tendency towards realistic representation of figures.

The second stage was during the $12^{\text {th }}$ and $13^{\text {th }}$ century, especially when the school of Mosul had developed a new understating of realism by presenting a wide variety of themes inspired of daily-life activities. Therefore, during that era we noticed unprecedented themes and lively scenes such as the aristocratic woman looking to a mirror or reclining on a couch.

The third stage of development was witnessed in Persian painting when painters presented a wide variety of scenes inspired from historic events, national epics, legends, famous romantic poems and religious stories. The Persian painting in general paid

\footnotetext{
${ }^{60} \mathrm{Pl} .8,12$ and 13

${ }^{61} \mathrm{Pl} .13$

${ }^{62} \mathrm{Pl} .15$

${ }^{63} \mathrm{Pl} .15$ and 16

${ }^{64} \mathrm{Pl} .13$ and 17
} 


\section{دراسات في آثار الوطن العربيء 1}

attention to human figures together with details of the nature and architectural elements around them. Moreover, during the $14^{\text {th }}$ century another step towards realism was achieved when portraiture was introduced into Persian painting ${ }^{65}$. That art became exceedingly popular in the later Timurid and especially the Safavid period ${ }^{66}$. The paintings represented portraits of contemporary individuals, thus, the paintings did not illustrate scenes common in other manuscripts but show unusual events which can be related to the life of the patron.

But achieving realism as a style associated with painting was in fact the contribution of Bihzad ${ }^{67}$ who broke down the remains of the old stiffness and formality ${ }^{68}$ and humanized the style by giving his figures realistic gestures and telling looks 69 . Bihzad depicted figures in greater variety of postures and attitudes, engaged in speech and gestures and that was considered a pictorial elaboration that went beyond the text's strict narrative requirements. Bihzad's creativity was in presenting a new trend in realism both in detail and in general iconography. He also introduced a psychological

\footnotetext{
${ }^{65}$ Sheila Blair, "The Development of the Illustrated Book in Iran”, Muqarnas, vol.10, 1993, p. 270

${ }^{66}$ E. Grübe, The Classical Style in Islamic Painting, p. 28

${ }^{67}$ Bihzad is known as Kamal al-Din Bihzad, and is considered the most famous Persian miniature-painter. He was probably born during the decade 1450-60 and was a pupil of Mirak Naqqash of Herat, the librarian of Sultan Husayn Baykara, who brought up the young orphan. Bihzad became recognized quickly and received great artistic opportunities. He remained in Heart for a long time then moved to Tabriz, the Safawid capital and was stayed under the patronage of Shah Isma'il. In 1522 he was appointed head of the royal library. Under Shah Tahmasp, Bihzad also received numerous marks of honour. As a result of Bihzad's fame his signature was added to miniatures for centuries and his works have been copied including the signature. The work that was surely attributed to him is the Bustan MS (893A.H./ 1488A.D.) that is preserved in the Egyptian National Library. Bihzad had a school of art that influenced Persian painting for centuries. For more detail see: Zaki M. Hassan, Funun al-Islam, Cairo, 1948, pp. 190-199; B. W. Robinson, Persian Drawings, pp. 20-22; Stuart Cary Welch, Royal Persian Manuscripts, London, 1976, pp.16-17; R. Ettinghausen, "Bihzad", Encyclopedia of Islam, vol. 1, Leiden, 1986, pp. 1211- 1214; Sheila Canby, Persian Painting, pp. 74-75; David J. Roxburgh, "Kamal al-Din Bihzad and Authorship in Persianate Painting”, Muqarnas, vol.17, 2000, pp. 119-146

${ }^{68}$ B. W. Robinson, Persian Paintings, London, 1952, p. 5

${ }^{69}$ Sheila Canby, Persian Painting, p. 75.
} 


\section{دراسات في آثار الوطن العربيء 1}

dimension of figures and mastered the depiction of everyday activities and the variety of facial features which stress diversity of figures $^{70}$. Bihzad had a number of successful students who worked in a style closely related to his. It was due to Bihzad's influence that a certain type of portrait painting and realistic rendering of the human figure flourished in Bukhara as in other schools of Persian painting $^{71}$. As a result a style marked with realism prevailed in Persian painting during the $16^{\text {th }}$ century on. Paintings became very live as if depicting shots of real life of sultans, aristocratic class and even poor people. The portraits were also depicting people from the real live. Those features were all witnessed in the paintings of the aristocratic women that were very live and depicted a variety of postures, facial features, expressions, clothes and headdresses.

\section{Summary}

Scenes of aristocratic women appeared in Islamic art as early as the eleventh century and continued till the seventeenth century with a wide variety of themes including enthroned woman, woman riding hawdag, woman looking at a mirror, woman reclining on a couch and portraits of women in different postures. Such scenes are a rich source of information about the fashions of clothes, headdresses, jewelry of aristocratic women through ages and their variation in different regions. The scenes also reflect preference of realism in depicting such themes, such style that had its early roots during the Fatimid era and reached its peak during the fifteenth century and was fully developed in Persian painting.

\footnotetext{
${ }^{70}$ David J. Roxburgh, "Kamal al-Din Bihzad", p. 121

${ }^{71}$ E. Grübe, The Classical Style in Islamic Painting, p. 32
} 


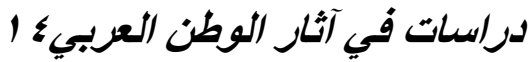

\section{Bibliography}

- Abbas Daneshvari, "Cup, Branch, Bird, and Fish: An Iconographical Study of the Figure Holding a Cup and a Branch Flanked by a Bird and a Fish", in The Iconography of Islamic Art; Studies in Honor of Robert of Hillenbrand, Bernard O'Kane (ed.), AUC, 2005, pp. 103-125.

- Abd al-Nasir Yasin, Wasa'el alsafar 'ind al Muslemin, Tarikhaha and atharaha-Derasa 'an alhawdag wa shakelatuh fi dawa almasader almaktuba wa alatharia, vol.1, Cairo, 2005.

- Ahmad Mousa Abd al-Tawab, Manazir al-Musiqa wa al-Tarab 'Ala al-Qitaa al-Faniya fi Misr al-Fatimia, Master Thesis, Faculty of Tourism and Hotels, Alexandria University, 2008.

- Barbra Brend, Islamic Art, London, 1991.

- Barbra Brend, "A Kingly Posture: the Iconography of Sultan Husayn Bayqara" in The Iconography of Islamic Art; Studies in Honor of Robert of Hillenbrand, Bernard O'Kane (ed.), AUC, 2005, pp.81-92.

- B. W. Robinson, Persian Paintings, London, 1952

- B. W. Robinson, Persian Drawings from the $14^{\text {th }}$ Century through the $19^{\text {th }}$ Century, London, 1965.

- David J. Roxburgh, "Kamal al-Din Bihzad and Authorship in Persianate Painting”, Muqarnas, vol.17, 2000, pp. 119-146.

- David Rice, "Inlaid Brasses from the Workshops of Ahmad alDhaki al-Mawsili", Ars Orientalis, 1957, pp. 283-325

- Doris Behrens-Abouseif, Beauty in Arabic Culture, 1999.

- E.J. Brill's First Encyclopedia of Islam, 1913-1936

- Ernst Grube, The Classical Style in Islamic Painting: The Early School of Heart and its Impact on Islamic Painting in the later $15^{\text {th }}$, $16^{\text {th }}$ and $17^{\text {th }}$ centuries, 1968.

- Ernst Kühnel, Miniaturmalerei im Islamischen Orient, Berlin, 1923. 


\section{دراسات في آثار الوطن العربي؛ 1}

- Eva Baer, "A Brass Vessel from the Tomb of Sayyid Battal Ghazi. Notes on the Interpretation of Thirteenth-Century Islamic Imagery", Artibus Asiae, vol. 39, n. 3/4, 1977

- Eva Baer, "The Human Figure in Early Islamic Art: Some Preliminary Remarks", Muqarnas, vol. 16, 1999, pp.32-41.

- Eva Wilson, Islamic Design, The British Museum Press, 1994

- Gawin R.G. Hambly (edit.), Women in the Medieval Islamic World, 1989

- Heba M. Saad and Delphine Dixneuf, Catalogue of the Faculty of Arts' Museum- Alexandria University, Islamic Pottery, Centre d'Étude Alexandrines, 2012

- J.A. Boyle, "InDju", The Encyclopedia of Islam, vol. III, LeidenLondon, 1986. p. 1208

- J. Jomier, "Mahmal", The Encyclopedia of Islam, vol. VI, Leiden, 1991, pp.44-46.

- Jonathan Bloom and Sheila Blair, Islamic Arts, 1997

- K.A.C. Creswell, Early Muslim Architecture, vol.1 -II, 1969.

- Kathryn Johnson, "Royal Pilgrims: Mamluk Accounts of the Pilgrimes to Mecca of the Khawand al-Kubra (Senior Wife of the Sultan)", Studia Islamica, n. 91, 2000, pp. 107- 131.

- Myriam Rosen-Aylon, "The Female Figure in Umayyad Art" in In Pursuit of Gender: Worldwide Archaeological Approaches, 2002.

- Oleg Graber, "Islamic Art and Byzantium", Dumbarton Oaks Papers, vol.18, 1964, pp.67-88

- Patricia Baker, Islamic Textiles, British Museum Press, 1995.

- Rachel Ward, Islamic Metalwork, 1993.

- Richard Ettinghausen, "Painting in the Fatimid Period: A Reconstruction", Ars Islamica, vol. 9, 1942, pp.112-124.

- Richard Ettinghausen, Arab Painting: Treasures of Islam, London, 1977.

- Richard Ettinghausen, "Bihzad", The Encyclopedia of Islam, vol.

1, Leiden, 1986, pp. 1211-1214.

- Richard Yeomans, The Art and Architecture of Islamic Cairo, 2006. 


\section{دراسات في آثار الوطن العربيء 1 أوان}

- Rina Talgam, The Stylistic Origins of Umayyad Sculpture and Architectural Decoration, 2004.

- Robert Hillenbrand, Islamic Art and Architecture, 1999

- Salah Bahnasi, Manazir al-Tarab wa al-Musiqa fi al-Taswir alIrani, 1990.

- Sheila Blair, "The Development of the Illustrated Book in Iran", Muqarnas, vol.10, 1993, pp.266-274

- Sheila R. Canby, Persian Painting, The British Museum, 1993

- Stuart Cary Welch, Royal Persian Manuscripts, London, 1976

- Walter Denny, "Music and Musicians in Islamic Art", Asian Music, vol.17, n.1, 1985, pp.37-68

- Wijdan Ali, The Arab Contribution to Islamic Art From the Seventh to the Fifteenth Centuries, 1998.

- Yedida Kalfon Stillman, Arab Dress from the Dawn of Islam to Modern Times- A short History, 2003

- Zaki M. Hassan, Al-Taswir fi al-Islam 'and al-Furs, 1936.

- Zaki M. Hassan, Funun al-Islam, Cairo, 1948. 


\section{دراسات في آثار الوطن العربي؛}

\section{Plates:}

Pl. 1

Pl.1-a

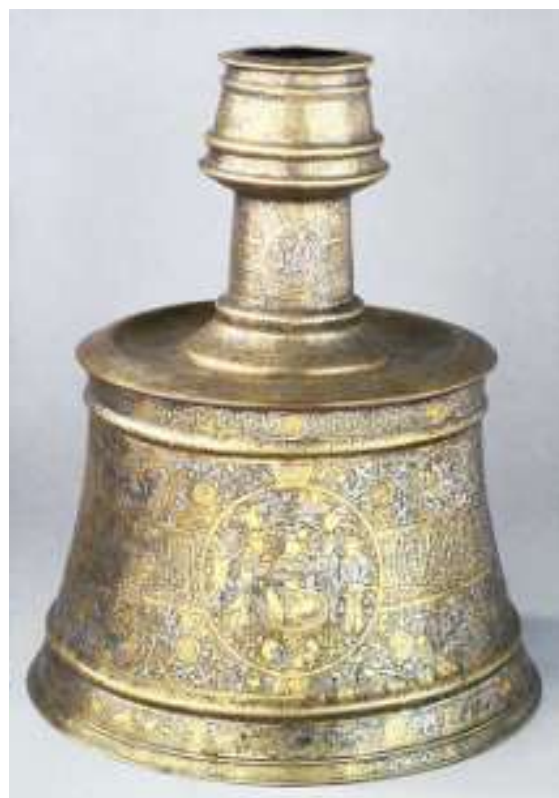

After: http://www.lacma.org/khan/5/2.htm

Pl. 1-b

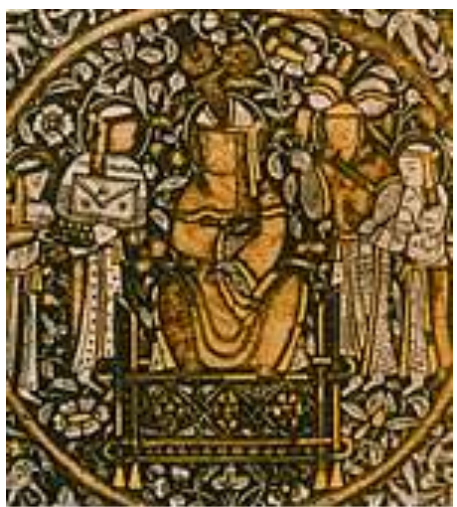

PI. 2

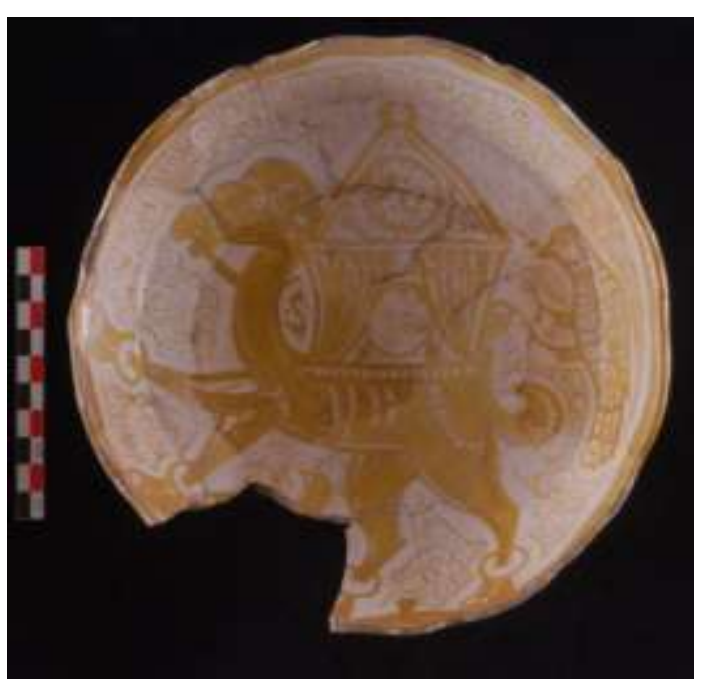

Photograph taken by the author 


\section{Pl. 3}

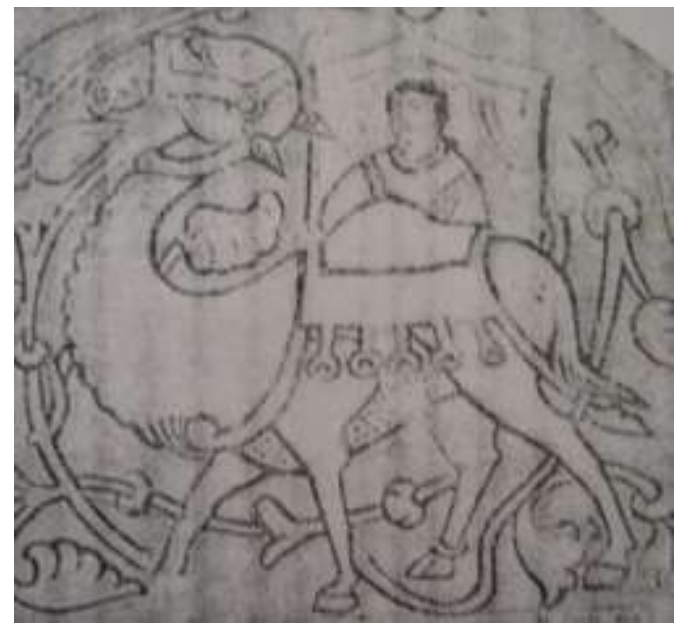

After: R. Ettinghausen, "Painting in the Fatimid Period", p.116, fig. 12

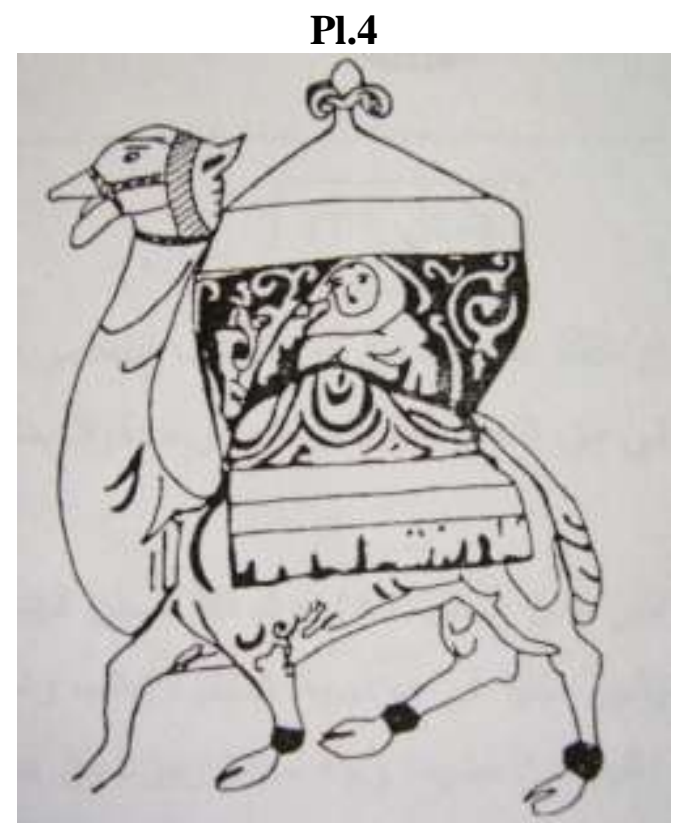

After: Abd al-Nasir Yasin, Wasa'el alsafar, vol.2, p.615, fig. 32 


\section{دراسات في آثار الوطن العربي؛ 1}

PI. 5

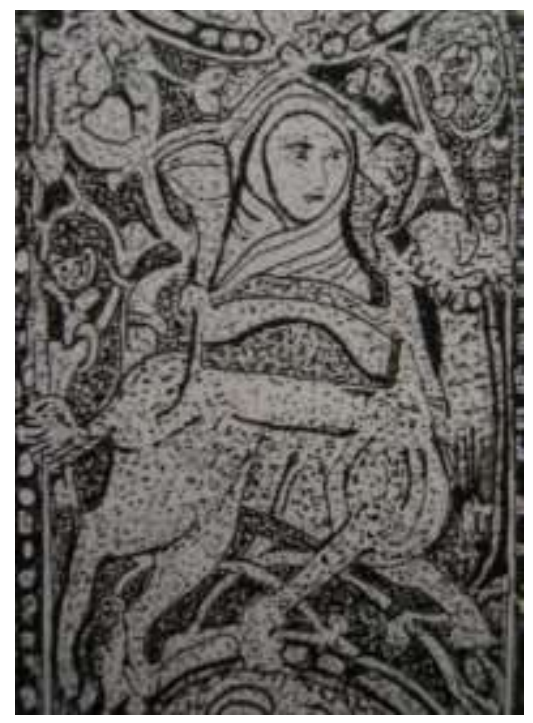

After R. Yeomans, The Art and Architecture, p.81

Pl. 6

Pl.6-a

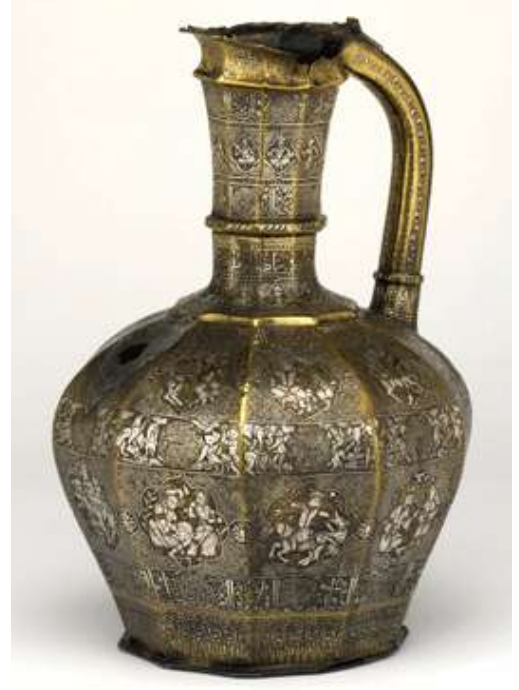

After:

Pl.6-b

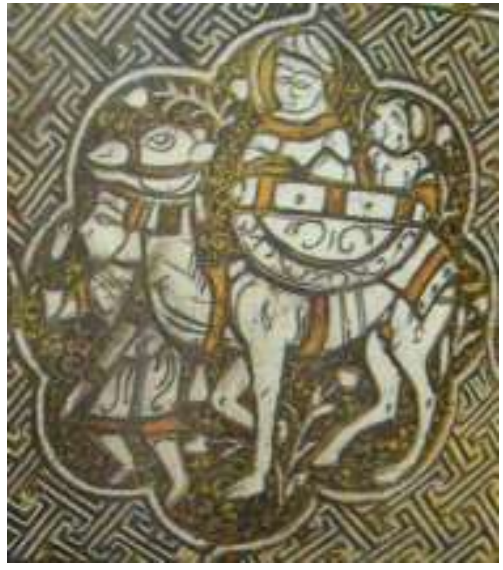

http://www.britishmuseum.org/explore/highlights/highlight_objects/me/t/the blacas_ewer.aspx 
دراسات في آثار الوطن العربيء 1

PI. 7

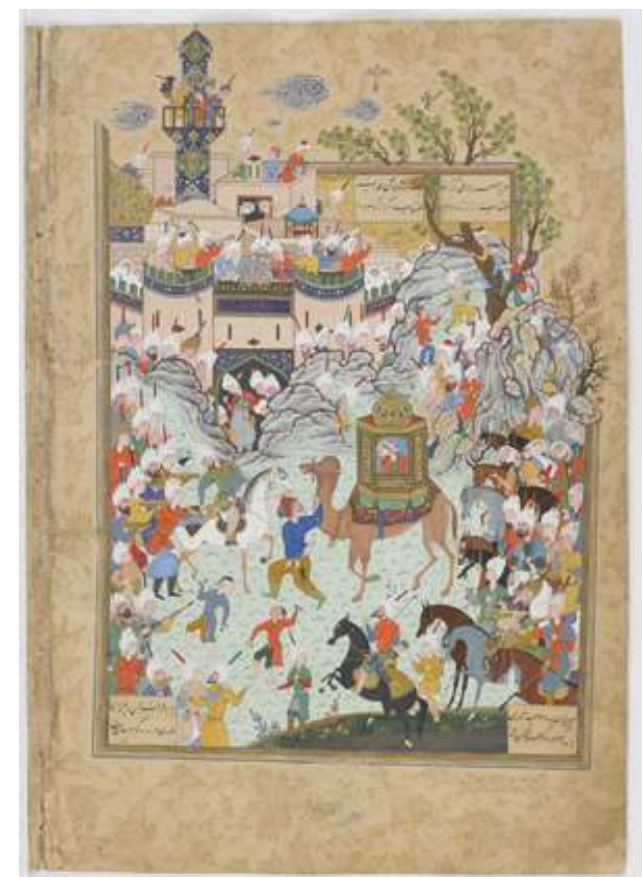

After:http://www.asia.si.edu/collections/singleObject.cfm?ObjectNumber=F19 $\underline{46.12 .100}$

PI. 8

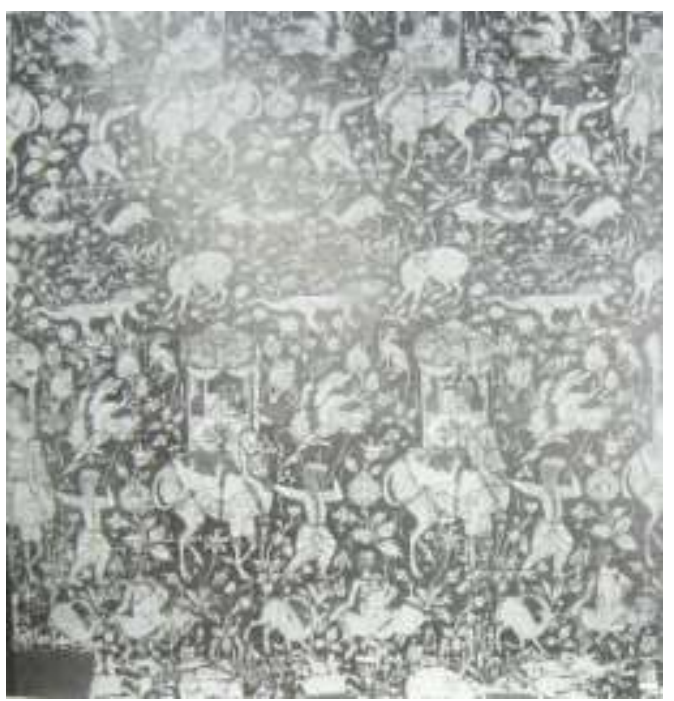

After: P. Baker, Islamic Textiles, p. 107 


\section{دراسات في آثار الوطن العربي؛ 1}

\section{Pl.9}

Pl. 9-a

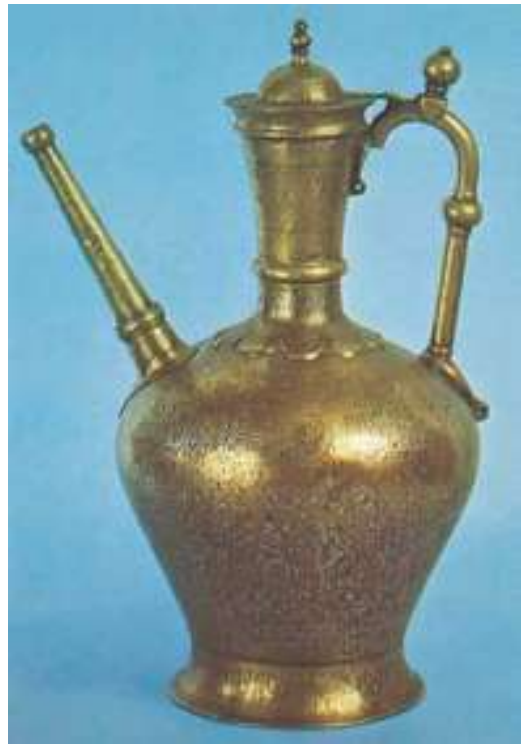

Pl. 6-b

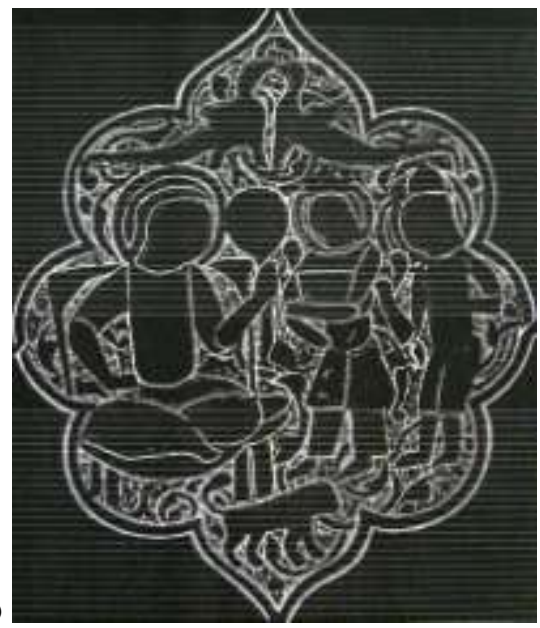

First photo after: http://www.britannica.com/EBchecked/media/72069/Mosul-brass-ewer1223-in-the-Cleveland-Museum-of-Art

Detail after: D. Rice, Inlaid Brasses, p. 294, fig. 13

Pl. 10

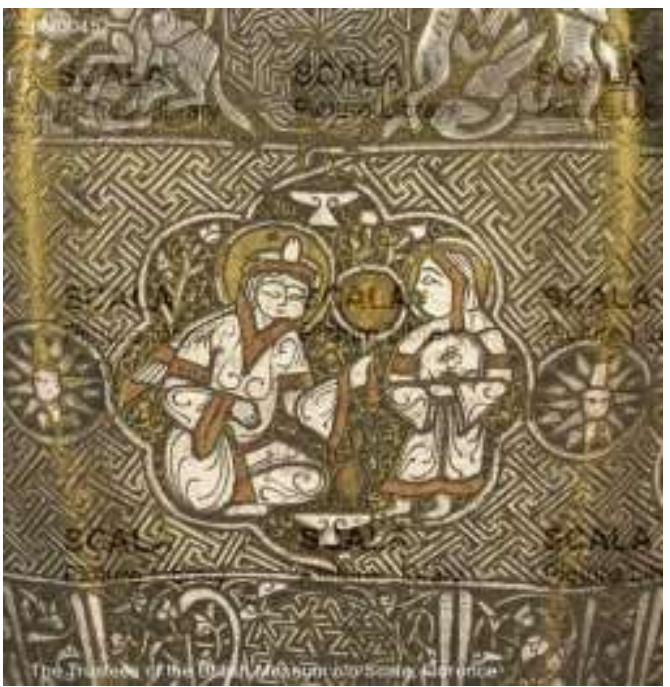

After:http://www.scalarchives.com/web/ricerca_risultati.asp?nRisPag=24\&prmset=on\&AND

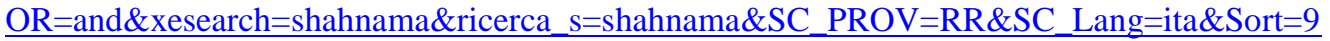




\section{دراسات في آثار الوطن العربي؛}

\section{PI. 11}

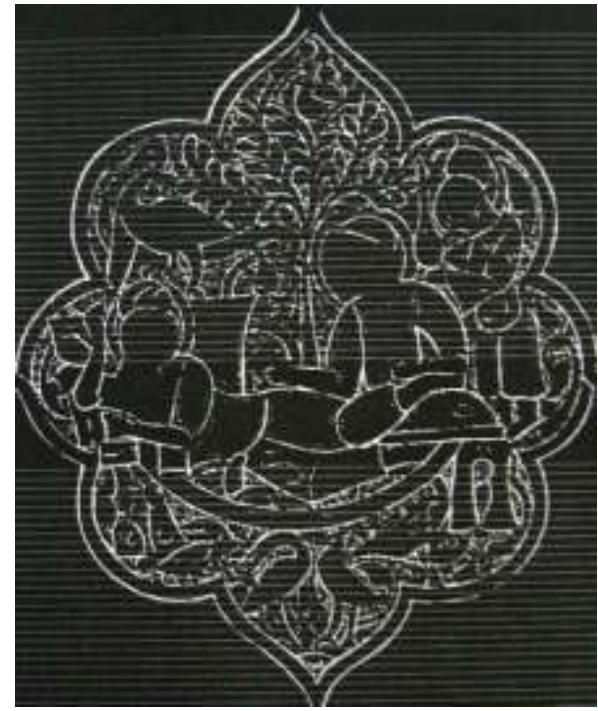

After: D. Rice, “Inlaid Brasses”, pp. 296, fig. 15

Pl.12

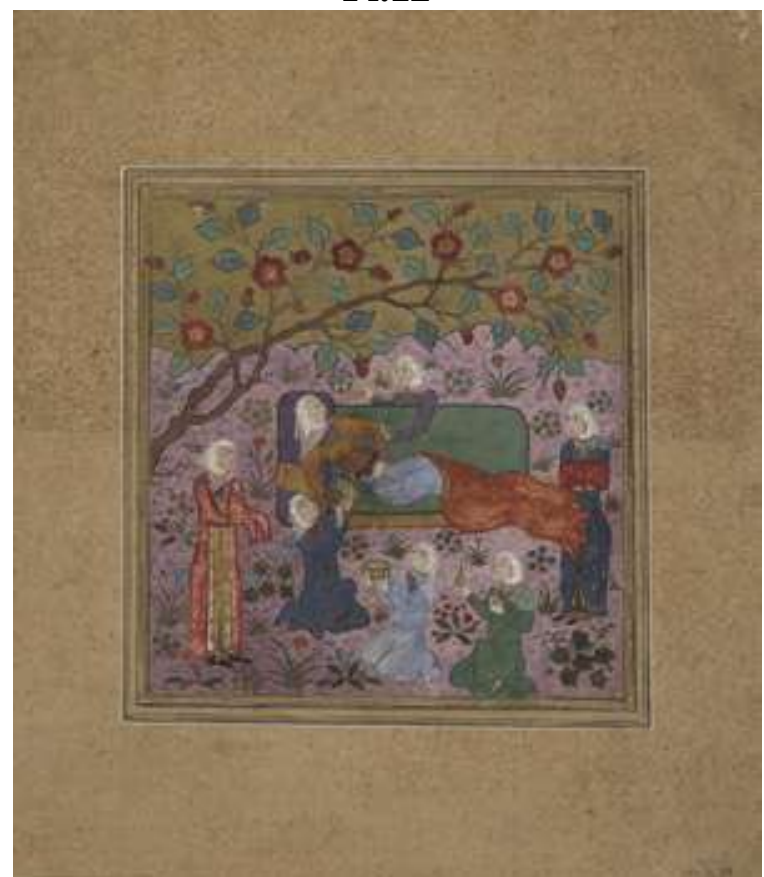

After:http://www.asia.si.edu/collections/singleObject.cfm?ObjectNumber=S19 $\underline{86.139}$ 


\section{Pl. 13}

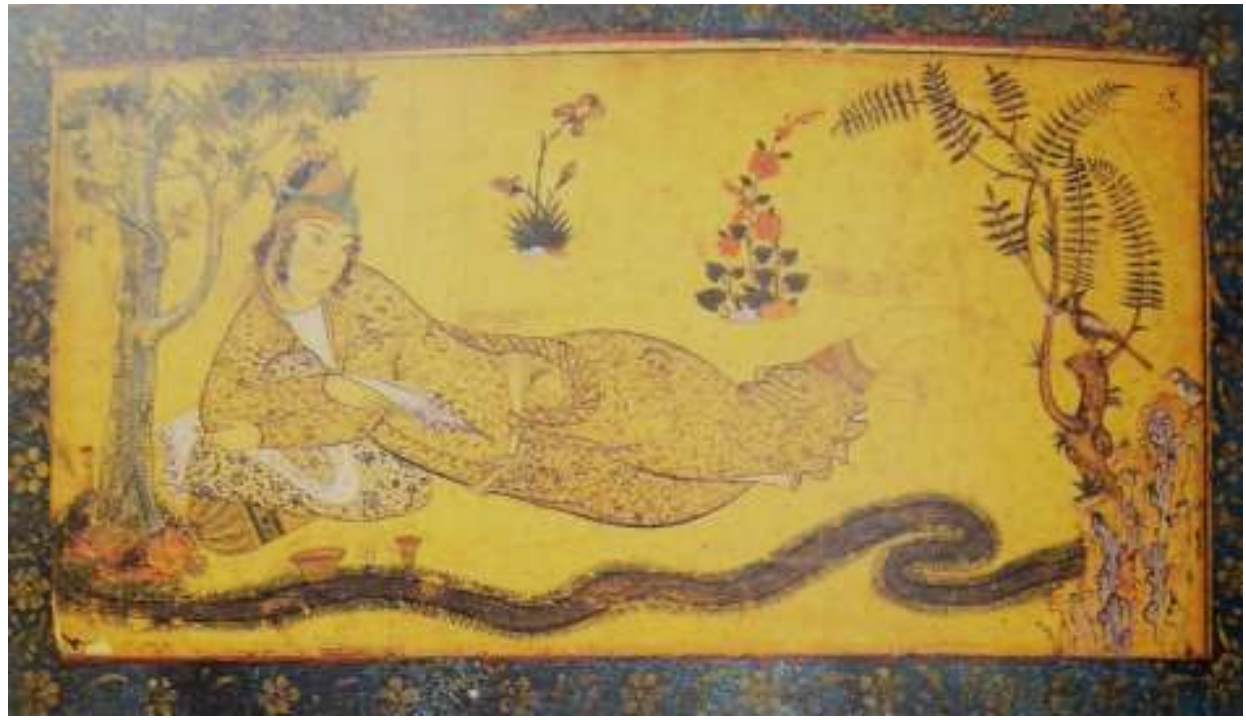

After: Barbra Brend, Islamic Art, pl.111

Pl.14

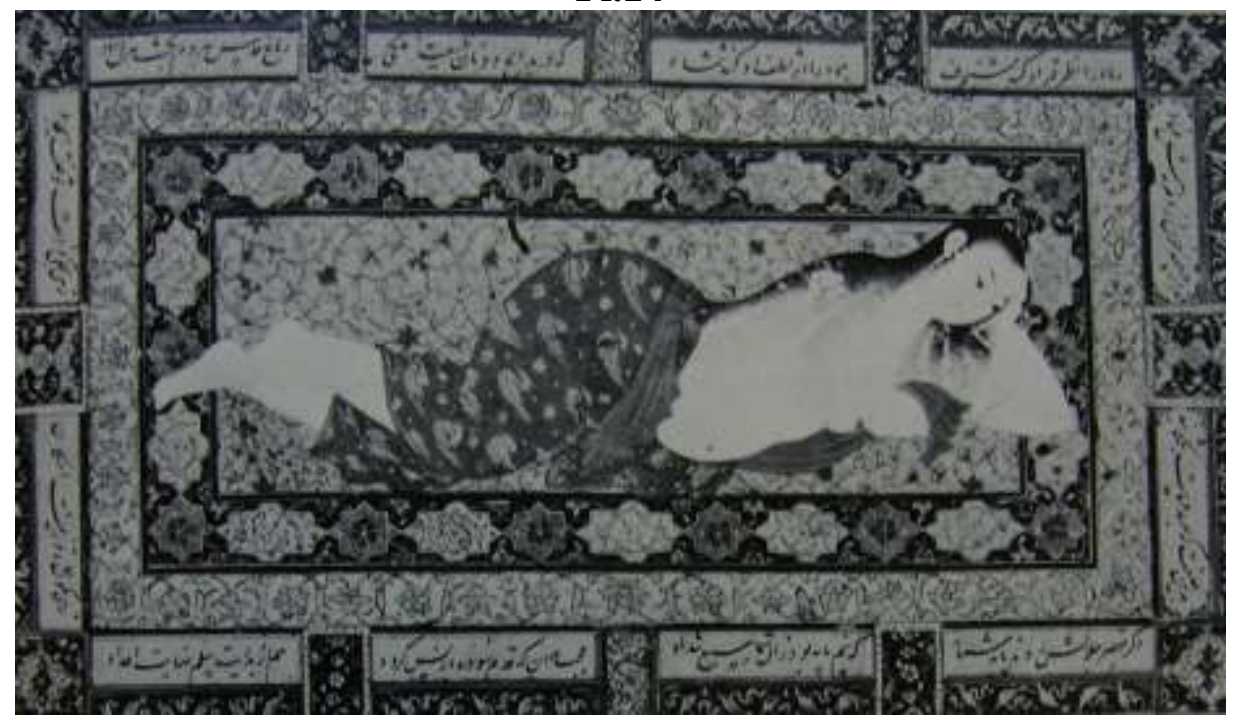

After: Ernst Kühnel, The Classical Style, pl. 50 
Pl. 15

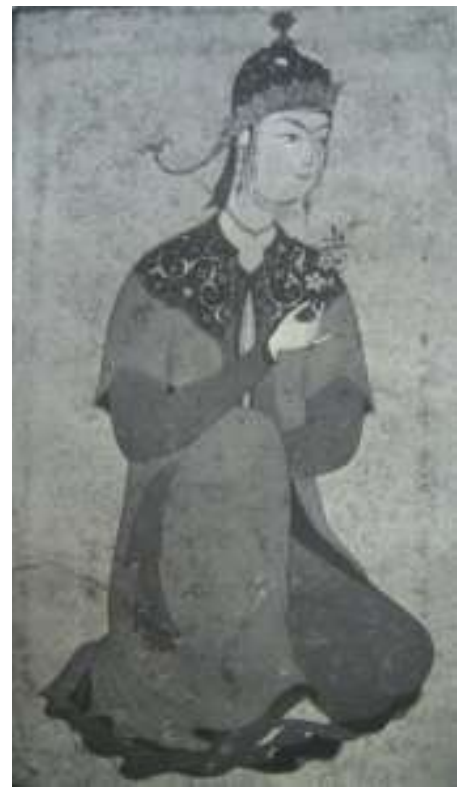

After: B.W. Robinson, Persian Drawings, pl.44

Pl. 16

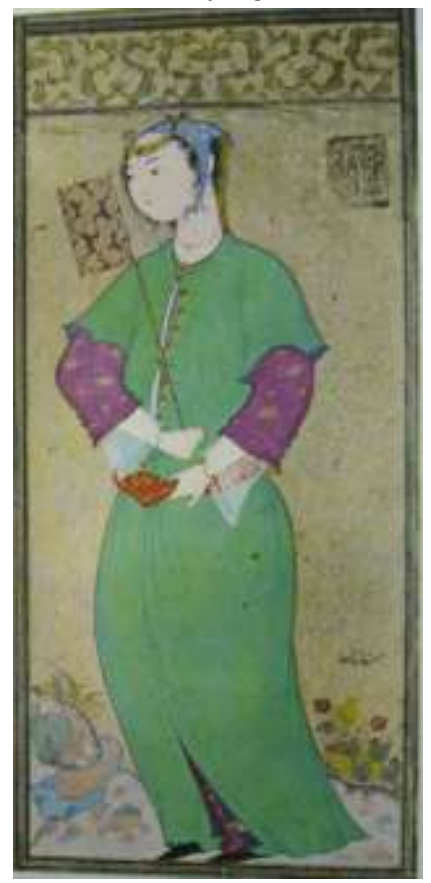

After: B.W. Robinson, Persian Drawings, pl.54 


\section{Pl.17}

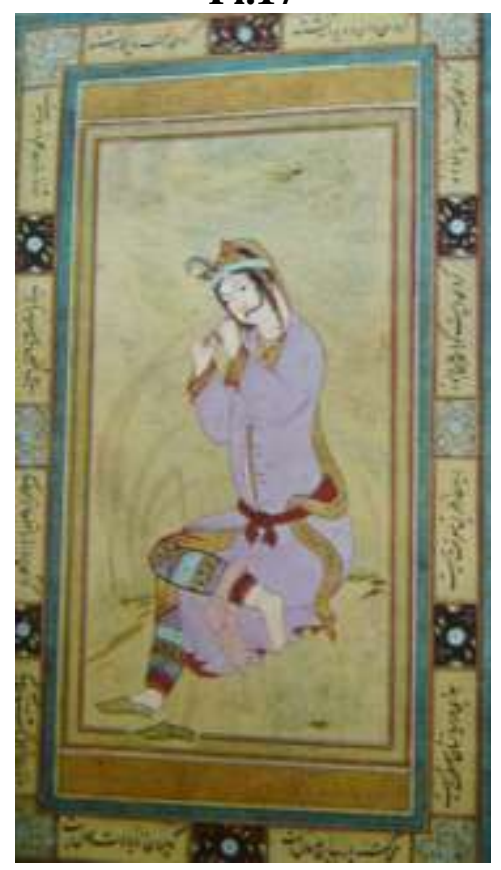

After: B.W. Robinson, Persian Drawings, pl.64

\section{PI. 18}

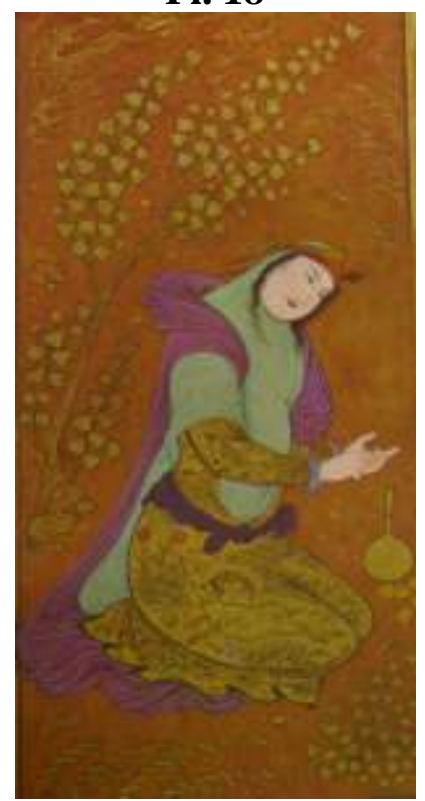

After: B.W. Robinson, Persian Drawings, pl.61 